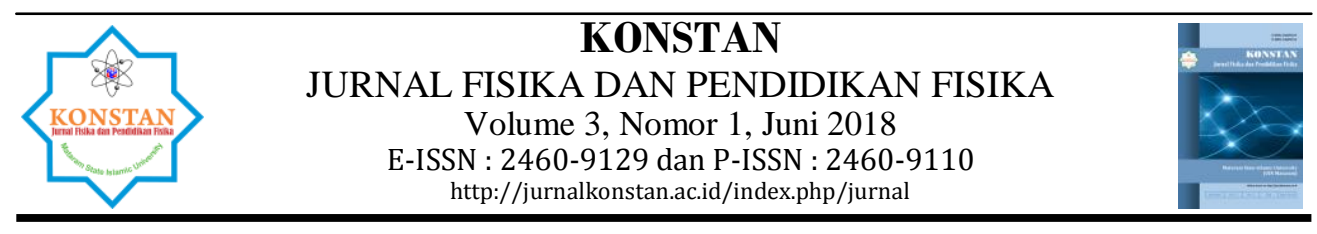

\title{
PENINGKATAN HASIL BELAJAR SISWA MELALUI PENDEKATAN PEMBELAJARAN OPEN-ENDED PADA MATA PELAJARAN FISIKA DI KELAS VIII SMP NEGERI 4 LINGSAR LOMBOK BARAT
}

\author{
Muhammad Kafrawi ${ }^{{ }^{*}}$ \\ ${ }^{1}$ Program Studi Tadris Fisika Fakultas Tarbiyah dan Keguruan UIN Mataram \\ Jln Gajah Mada 100 Jempong Mataram
}

\section{Info Artikel}

Sejarah Artikel:

Diterima Juni 2018

Disetujui Juli 2018

Dipublikasikan Juli 2018

\section{Kata Kunci:}

Pendekatan Pembelajaran Open-Ended, Hasil Belajar, Aktivitas Belajar

\begin{abstract}
Abstrak
Penelitian ini merupakan Penelitian Tindakan Kelas (PTK) yang bertujuan untuk mengetahui peningkatan hasil belajar dan aktivitas belajar siswa melalui pendekatan pembelajaran Open-Ended pada mata pelajaran fisika di kelas VIII $_{\mathrm{A}} \mathrm{SMP}$ Negeri 4 Lingsar Lombok Barat tahun ajaran 2015/2016. Subjek penelitian ini adalah siswa kelas VIII $_{\mathrm{A}}$ SMP Negeri 4 Lingsar Lombok Barat tahun ajaran 2015/2016 sedangkan objek penelitiannya adalah hasil dan aktivitas belajar siswa yang diperoleh dari hasil evaluasi di setiap akhir siklus dan aktivitas belajar siswa yang diperoleh dari hasil observasi selama pelaksanaan tindakan. Pada siklus I diperoleh nilai rata-rata kelas 61.15 dengan ketuntasan klasikal $71.45 \%$ dan rata-rata skor aktivitas belajar siswa 35 dengan kategori kurang aktif. Pada siklus II data hasil dan aktivitas siswa mengalami peningkatan yakni rata-rata kelas sebesar 72.28 dengan ketuntasan klasikal $87.52 \%$ dan skor rata-rata aktivitas belajar siswa 67 dengan kriteria aktif. Pada siklus III nilai rata-rata kelas meningkat menjadi 85.49 dengan ketuntasan klasikal $95.29 \%$ dan rata-rata skor aktivitas belajar siswa 70 dengan kriteria sangat aktif. Dengan demikian dapat disimpulkan bahwa pendekatan pembelajaran Open-Ended dapat meningkatkan hasil dan aktivitas belajar siswa di kelas VIII $_{\mathrm{A}}$ SMP Negeri 4 Lingsar Lombok Barat tahun pelajaran 2015/2016.
\end{abstract}

(C) 2018 Universitas Islam Negeri Mataram

Alamat korespodensi:

Gedung Pasca Sarjana Lantai 3 Kampus 2 UIN Mataram, Jl. Gajah Mada 100 Jempong Mataram, Indonesia Email: jurnalkonstan@uinmataram.ac.id 


\section{PENDAHULUAN}

Metode mengajar IPA/fisika di sekolah dasar dan sekolah menengah bahkan juga di perguruan tinggi ialah metode mengajar secara informatif yaitu guru berbicara atau bercerita dan siswa mendengarkan dan mencatat. Secara tradisional, pengajaran IPA/fisika ditekankan pada penghafalan rumus-rumus atau bentuk-bentuk problem tertentu. Pengajaran IPA lebih menekankan pada produkproduk daripada proses-proses.

Untuk itu harus ada pendekatan dan metode pembelajaran yang efektif dalam menyampaikan materi fisika pada siswa. Vendiagrys (2007) menjelaskan pembelajaran yang efektif dapat membantu peserta didik untuk meningkatkan kemampuan sesuai dengan kompetensi dasar yang harus dicapai [1]. Untuk meningkatkan cara belajar yang efektif perlu diperhatikan kondisi internal, eksternal serta strategi dan model pembelajaran yang digunakan. Pembelajaran yang efektif akan terlaksana jika guru dapat memilih strategi dan model pembelajaran yang tepat sehingga tercapai hasil yang semaksimal mungkin. Dalam pembelajaran guru harus mengajar secara efektif dan mengajar bagaimana peserta didik belajar. Dalam pembelajaran yang efektif, guru harus banyak memberi kebebasan kepada peserta didik untuk dapat menyelidiki, mengamati, belajar, dan mencari pemecahan masalah secara mandiri.

Berdasarkan kenyataan di atas dibutuhkan sebuah pendekatan pembelajaran yang dapat membantu peserta didik agar lebih memahami konsep-konsep dalam pembelajaran fisika yang tidak hanya berorientasi pada hasil akan tetapi pada proses dalam pemecahan masalah. Suherman (2001) mengatakan bahwa dalam pembelajaran dengan pendekatan Open-Ended, siswa diharapkan bukan hanya mendapatkan jawaban tetapi lebih menekankan pada proses pencarian suatu jawaban [2]. Berdasarkan hasil observasi yang dilakukan oleh penulis terdapat kesulitan dalam menyelesaikan masalah-masalah fisika yang diberikan karena siswa cenderung terpaku pada cara penyelesian masalah yang diberikan oleh guru tanpa berani mencoba inisiatif lain untuk menyelesaikan masalah tersebut. Keleluasaan berpikir melalui pendekatan Open-Ended problem membawa siswa untuk lebih memahami suatu topik dan keterkaitannya dengan topik lainnya baik dalam pelajaran matematika maupun dengan mata pelajaran lain dari dalam kehidupan sehari-hari. Oleh karena itu pendekatan Open-Ended tidak hanya dapat digunakan untuk menyelesaikan permasalahan dalam mata pelajaran matematika akan tetapi pada mata pelajaran lain yang membutuhkan matematika sebagai alat bantu dalam menyelesaikan permasalahan-permasalahan terutama mata pelajaran fisika. Oleh karena itu peneliti ingin mengangkat masalah tersebut pada sebuah penelitian yang berjudul "Peningkatan Hasil Belajar Siswa dengan Pendekatan Pembelajaran OpenEnded pada Mata Pelajaran Fisika di Kelas VIII SMP Negeri 4 Lingsar Lombok Barat".

\section{A. Batasan Masalah}

Dalam penelitian ini, ada beberapa hal yang perlu dibatasi antara lain:

1. Pendekatan pembelajaran yang dimaksud adalah pendekatan dengan masalah terbuka (Open-Ended). 
2. Hasil belajar yang dimaksud adalah hasil belajar kognitif siswa yang dicapai melalui proses aktivitas pembelajaran dengan pendekatan OpenEnded.

3. Pelajaran fisika yang dimaksud adalah materi pelajaran fisika kelas $\mathrm{VIII}_{\mathrm{A}}$ semester II tahun ajaran 2015/2016 pokok bahasan Getaran dan Gelombang.

\section{B. Rumusan Masalah}

Adapun rumusan masalah yang dapat diambil dari penelitian ini adalah "Bagaimana peningkatan hasil belajar dan aktivitas belajar siswa melalui pendekatan pembelajaran Open-Ended pada mata pelajaran fisika di kelas $\mathrm{VIII}_{\mathrm{A}}$ SMP Negeri 4 Lingsar Lombok Barat?"

\section{Tujuan Penelitian}

Untuk mengetahui peningkatan hasil belajar dan aktivitas belajar siswa melalui pendekatan pembelajaran Open-Ended pada mata pelajaran fisika di kelas $\mathrm{VIII}_{\mathrm{A}}$ SMP Negeri 4 Lingsar Lombok Barat.

\section{Manfaat Penelitian}

Adapun beberapa manfaat yang diharapkan oleh penulis setelah melakukan penelitian ini antara lain:

1. Dapat memberikan masukan pada guru untuk mempermudah pencapaian tujuan pembelajaran dengan menggunakan pendekatan Open-Ended dalam kegiatan pembelajaran.

2. Memberikan masukan pada guru dalam melangsungkan proses pembelajaran yakni dengan menggunakan pendekatan pembelajaran OpenEnded yang menawarkan masalah terbuka dengan banyak cara dan/atau banyak penyelesaian.

3. Membantu mempermudah siswa memahami materi pelajarannya dan menyelesaikan permasalahannya dengan caranya sendiri tanpa harus terpaku pada penyelesaian yang diberikan guru.

4. Memberikan masukan pada mahasiswa untuk dapat mengembangkan pendekatan pembelajaran Open-Ended dalam proses pembelajaran baik dalam perkuliahan maupun pada pembelajaran di sekolah.

\section{E. Definisi Operasional}

1. Hasil belajar adalah hasil yang diperoleh dari aktivitas belajar fisika melalui pendekatan pembelajaran Open-Ended yang dilihat secara nyata berupa skor atau nilai setelah mengerjakan suatu tes.

2. Pendekatan pembelajaran adalah serangkaian kegiatan pembelajaran dalam rangka mencapai tujuan pendidikan.

3. Pendekatan pembelajaran Open-Ended adalah pendekatan pembelajaran yang menyajikan suatu permasalahan yang memiliki metode atau penyelesaian yang benar lebih dari satu. 


\section{METODE PENELITIAN}

\section{A. Jenis Penelitian}

Penelitian ini adalah penelitian tindakan kelas yang merupakan suatu model penelitian yang dikembangkan di kelas, menurut Iskandar (2009) penelitian tindakan kelas (PTK) merupakan bagian dari penelitian tindakan (action research) yang dilakukan oleh guru dan dosen di kelas (sekolah dan perguruan tinggi) tempat ia mengajar yang bertujuan memperbaiki dan meningkatkan kualitas dan kuantitas proses pembelajaran di kelas [3].

\section{B. Waktu dan tempat penelitian}

Penelitian ini dilaksanakan pada tanggal 15 sampai 29 April 2016. Penelitian ini dilakukan di SMP Negeri 4 Lingsar pada siswa kelas VIII $_{\mathrm{A}}$ semester II.

\section{Subyek Penelitian}

Subyek penelitian ini adalah siswa kelas VIII $_{\mathrm{A}}$ SMP Negeri 4 Lingsar Lombok Barat tahun ajaran 2015/2016.

\section{Prosedur Penelitian}

Prosedur penelitian tindakan kelas ini terdiri dari tiga siklus, tiap siklus dilaksanakan sesuai dengan perubahan yang ingin dicapai seperti apa yang dirancang dalam faktor yang diselidiki. Adapun tindakan dari tiap siklus adalah sebagai berikut:

\section{Silkus $I$}

a. Perencanaan

Adapun kegiatan yang dilakukan pada tahap ini adalah sebagai berikut:

1) Membuat rencana pembelajaran untuk pokok bahasan getaran dan gelombang.

2) Menyusun beberapa pertanyaan dengan masalah terbuka.

3) Menyiapkan jawaban dari masalah-masalah tersebut.

4) Menuliskan respon siswa yang diharapkan (daftar antisipasi respon peserta didik terhadap masalah).

b. Pelaksanaan

Langkah pembelajaran meliputi kegiatan awal, kegiatan inti dan kegiatan akhir. Kegiatan inti mencakup pemberian masalah, merekam respon yang diharapkan dari siswa, pembahasan respon siswa dan meringkas atas apa yang telah dipelajari. Adapun langkah pembelajarannya adalah sebagai berikut: 
a. Kegiatan awal

1) Guru melakukan tanya jawab untuk mengecek pengetahuan prasyarat dan keterampilan yang dimiliki siswa.

b. Kegiatan inti

1) Memberikan masalah

Guru memberikan masalah Open-Ended yang berkaitan dengan materi yang diajarkan sehingga siswa dapat memahaminya dan menemukan pendekatan penyelesaiannya

2) Mengeksplorasi masalah

Waktu mengeksplorasi masalah digunakan oleh siswa untuk menyelesaikan masalah yang diberikan. Mengeksplorasi masalah dibedakan menjadi beberapa sesi, sesi pertama yaitu kerja individu dan sesi kedua mendiskusikan hasil pekerjaan individu dengan teman sebangku.

3) Merekam respon siswa

Guru meminta beberapa orang siswa sebagai wakil untuk mengemukakan jawabannya tentang masalah yang diberikan.

4) Pembahasan respon siswa (diskusi kelas)

Guru mencatat respon siswa, pendekatan atau solusi masalah mereka dan menulis sebanyak mungkin kemungkinan respon siswa dan mendaftarnya. Dalam proses diskusi kelas guru mendorong siswa agar dapat memberikan jawaban dan kesimpulan tentang konsep yang diajarkan

5) Meringkas apa yang dipelajari

Dalam kegiatan ini guru dan siswa membuat kesimpulan tentang materi yang telah dipelajari.

c. Kegiatan akhir

1) Guru memberikan informasi tentang materi yang akan dipelajari pada pertemuan berikutnya.

c. Observasi/Evaluasi

Pada tahap ini dilaksanakan evaluasi terhadap hasil belajar siswa dengan pendekatan Open-Ended selama pembelajaran fisika berlangsung.

d. Refleksi

Hasil yang diperoleh pada tahap sebelumnya dikumpulkan dan dianalisis pada tahap refleksi sehingga dari hasil analisis tersebut pengajar dapat merefleksikan diri dengan melihat data hasil analisis apakah kegiatan yang dilakukan dapat meningkatkan prestasi belajar siswa dalam mempelajari fisika. Hasil analisis data yang diperoleh pada tahap ini akan dipergunakan sebagai acuan untuk merencanakan siklus berikutnya.

\section{Siklus II dan siklus III}

Prosedur pelaksanaan penelitian pada siklus II dan III sama seperti pada siklus I dengan memperhatikan hasil refleksi siklus I sebagai acuan perbaikan. Perbedaannya hanyalah pada materi yang dipelajari, pada siklus I materinya "Getaran" sedangkan pada siklus II dan siklus III materinya adalah "Gelombang". 
Adapun secara ringkas tahap-tahap kegiatan dalam penelitian tindakan kelas ini adalah:

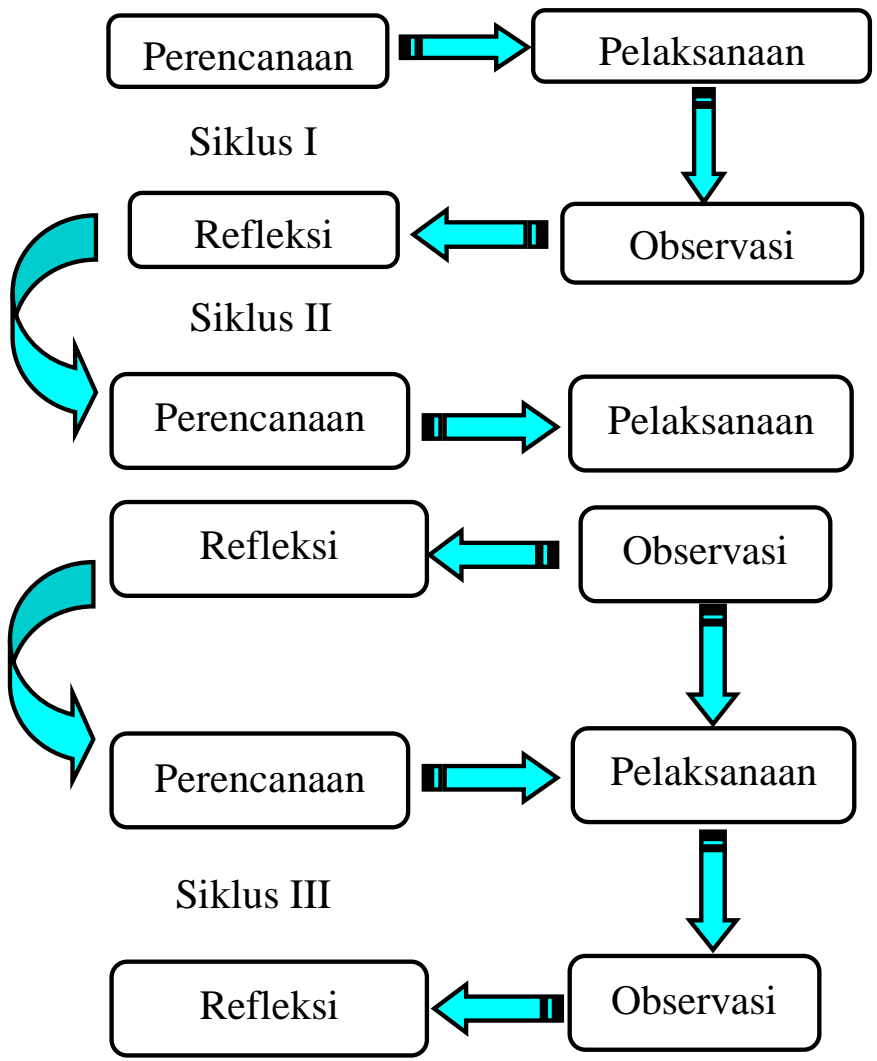

Gambar 1. Tahap-Tahap Kegiatan Penelitian Tindakan Kelas [1]

\section{E. Teknik pengumpulan data}

Penelitian ini bertujuan untuk meningkatkan kemampuan pemecahan masalah pada pembelajaran fisika, pemecahan masalah tidak hanya dilihat dari benar atau salah hasil perhitungan siswa, tetapi juga dilihat dari kemampuan siswa dalam menyelesaikan soal, kemampuan siswa dalam memahami masalah, mengorganisasi data dan menyajikan masalah dalam berbagai bentuk, mengembangkan strategi pemecahan masalah, serta membuat dan menafsirkan model dari suatu masalah, maka dalam penelitian ini digunakan soal essay pengumpulan data, soal essay diberikan pada tiap akhir siklus untuk mengetahui ketuntasan belajarnya.

\section{F. Teknik analisis data}

1. Teknik analisa validitas data

2. Teknik analisa data aktivitas a. Aktivitas Guru 


\section{b. Aktivitas Siswa}

3. Teknik analisa data hasil belajar

a. Data ketuntasan belajar

b. Data nilai rata-rata kelas

\section{HASIL DAN PEMBAHASAN}

Setelah dilakukan tindakan dengan menerapkan pendekatan pembelajaran OpenEnded pada pokok bahasan Getaran dan Gelombang di kelas VIII $\mathrm{S}_{\mathrm{A}}$ SMP Negeri 4 Lingsar diperoleh hasil berupa data hasil dan aktivitas siswa dan dianalisis menggunakan metode yang telah ditentukan sebelumnya. Jumlah siswa kelas VIII $_{\mathrm{A}}$ yang mengikuti tes evaluasi adalah 35 orang.

Pada siklus I dari 35 orang siswa yang mengikuti tes evaluasi, hanya 25 orang yang dinyatakan tuntas (nilai $\geq 60$ ) atau sekitar $71.45 \%$ dengan nilai rata-rata kelas sebesar 61.15. Hasil ini belum memenuhi ketuntasan yang diinginkan yakni $85 \%$ atau sekurang-kurangnya 30 orang siswa maka penelitian harus dilanjutkan ke siklus berikutnya. Demikian juga dengan nilai rata-rata aktivitas belajar siswa masih berada pada interval 22,5 $\leq \mathrm{x}<37,5$ yakni sebesar 35 dengan kriteria kurang aktif. Pada saat diberikan permasalahan tipe Open-Ended sebagian besar siswa tidak mengerti maksud pertanyaan dari permaslahan yang diberikan akibatnya muncul banyak sekali pertanyaan dari siswa demikian pula dalam tahap diskusi dengan teman sebangku masih banyak siswa yang tidak serius, hal ini terjadi karena jawaban dari permasalahan Open-Ended yang telah mereka kerjakan secara individu kebanyakan sama dengan teman sebangkunya. Demikian pula pada tahap pembahasan respon siswa melalui diskusi kelas hanya sedikit siswa yang maju dan mengerjakan permasalahan yang diberikan di papan tulis, hanya siswa yang pintar yang mendominasi kegiatan ini, akibatnya siswa dengan kemampuan lebih rendah tidak pernah mengemukakan idenya tentang masalah-masalah yang diberikan. Dari hasil pembahasan respon siswa pada siklus I ini jawaban siswa tidak terbuka, siswa masih kurang percaya diri dalam mengembangkan ide-idenya, mereka telah terbiasa dengan permasalahan-permaslahan Close Ended yang menawarkan hanya satu jawaban atas satu permasalahan yang diberikan. Oleh karena itu dari 2 permasalahan yang diberikan siswa hanya memperoleh masing-masing 1 jawaban atas permasalahan tesebut.

Pada siklus II diadakan beberapa perbaikan pada tindakan selama proses pembelajaran sehingga terdapat peningkatan data hasil belajar siswa yakni dari data ketuntasan klasikal siklus I sebesar $71.45 \%$ meningkat menjadi $87.52 \%$ pada siklus II yakni 31 orang dari 35 orang siswa yang dikatakan tuntas, demikian pula dengan nilai rata-rata aktivitas belajar siswa mengalami peningkatan yakni dari 35 pada siklus I dengan kriteria kurang aktif menjadi 67 pada siklus II dengan kriteria aktif. Pada siklus II ini hanya ada 2 orang siswa yang bertanya tentang maksud dari permasalahan yang diberikan hal ini terjadi karena pada siklus II ini guru mencoba untuk menyederhanakan bahasa dalam soal yang diberikan dengan menggunakan bahasa yang dapat dimengerti oleh siswa dan membuat permasalahan Open-Ended yang diberikan sesuai dengan tingkat pengetahuan dan daya serap siswa. Hal ini Pada dasarnya pendekatan Open-Ended bertujuan untuk mengangkat kegiatan kreatif siswa. Oleh karena itu hal yang perlu diperhatikan adalah kebebasan siswa untuk membuat pemecahan masalah sesuai dengan kemampuannya [2]. 
Kegiatan siswa pada siklus II dikatakan terbuka karena dari 2 permasalahan Open-Ended yang diberikan, siswa dapat menjawab dengan lebih dari satu jawaban yang benar, sehingga pada saat berdiskusi dengan teman sebangku siswa menjadi lebih termotivasi untuk menemukan sebanyak mungkin jawaban dari permasalahan yang diberikan. Karena tujuan dari pembelajaran dengan pendekatan Open-Ended ini adalah agar respon siswa menjadi beragam atas masalah yang diberikan [2]. Pada siklus I dalam pembahasan respon siswa melalui diskusi kelas, yang mendominasi kegiatan ini hanya siswa yang pintar. Oleh karena itu pada siklus II guru mengadakan perbaikan dengan meminta siswa dengan kemampuan yang lebih rendah untuk terlebih dahulu mengemukakan pendapatnya tentang masalah yang diberikan kemudian setelah itu barulah siswa yang pintar melengkapi kekurangan jawaban temannya. Dengan cara seperti ini baik siswa yang berkemampuan tinggi ataupun rendah sama-sama memiliki kemampuan untuk mengemukakan pendapatnya.

Pada siklus III diadakan beberapa perbaikan untuk menyempurnakan hasil yang diperoleh pada siklus II sehingga pada siklus III terjadi peningkatan prestasi belajar siswa yakni peningkatan nilai rata-rata kelas dari 72.28 pada siklus II menjadi 85.49 pada siklus III serta peningkatan ketuntasan klasikal dari $87.52 \%$ pada siklus II menjadi $95.29 \%$ yakni 33 orang dari 35 siswa yang dikatakan tuntas pada siklus III. Aktivitas belajar siswa juga mengalami peningkatan pada siklus III ini yakni dari skor 67 pada siklus II dengan kriteria aktif menjadi 70 pada siklus III dengan kriteria sangat aktif. Permasalahan Open-Ended yang diberikan juga dapat dijawab dengan lebih banyak variasi dari siklus sebelumnya.

Hasil penelitian dan analisis data yang didapatkan menunjukkan bahwa hasil dan aktivitas belajar siswa meningkat dari siklus I, siklus II dan siklus III. Hasil ini menunjukkan bahwa penerapan pendekatan pembelajaran Open-Ended dapat meningkatkan hasil dan aktivitas belajar fisika siswa VIII ${ }_{\mathrm{A}}$ SMP Negeri 4 Lingsar pada pokok bahasan Getaran dan Gelombang. Sehingga pendekatan pembelajaran Open-Ended dapat digunakan sebagai alternatif untuk pembelajaran siswa di sekolah.

\section{SIMPULAN DAN SARAN}

\section{Kesimpulan}

Pendekatan pembelajaran Open-Ended telah berhasil dalam meningkatkan hasil belajar fisika siswa kelas $\mathrm{VIII}_{\mathrm{A}}$ SMP Negeri 4 Lingsar tahun pelajaran 2015/2016 pada pokok bahasan Getaran dan Gelombang. peningkatan prestasi belajar siswa terlihat dengan adanya peningkatan ketuntasan klasikal yaitu untuk siklus I sebesar $71.45 \%$ dengan rata-rata kelas sebesar 61.15 meningkat pada siklus II menjadi $87.52 \%$ dengan rata-rata kelas sebesar 72.28. kemudian pada siklus III nilai rata-rata kelas meningkat menjadi 85.49 dengan ketuntasan klasikal sebesar 95.29\%.

Pendekatan pembelajaran Open-Ended telah berhasil dalam meningkatkan aktivitas belajar fisika siswa kelas VIII $_{\mathrm{A}}$ SMP Negeri 4 Lingsar tahun pelajaran 2015/2016 pada pokok bahasan Getaran dan Gelombang. Peningkatan aktivitas belajar fisika siswa terlihat dari adanya peningkatan skor rata-rata aktivitas belajar 
siswa yaitu untuk siklus I sebesar 35 dengan kriteria kurang aktif menjadi 67 pada siklus II dengan kriteria aktif dan 70 pada siklus III dengan kriteria sangat aktif.

\section{Saran}

Bagi guru mata pelajaran fisika diharapkan bisa menggunakan pendekatan pembelajaran Open-Ended dalam kegiatan pembelajaran di kelas untuk meningkatkan hasil dan aktivitas belajar siswa.

Dalam pembelajaran dengan pendekatan Open-Ended diharapkan guru merancang pembelajaran dengan sebaik mungkin seperti menyediakan buku penunjang yang memadai dan mengatur alokasi waktu sebaik-baiknya

Untuk peneliti selanjutnya yang ingin mengangkat pendekatan pembelajaran Open-Ended pada penelitiannya bisa menerapkannya pada materi lain.

\section{DAFTAR PUSTAKA}

[1] Vendiagrys, Lia. 2007. Kefektifan Pembelajaran Matematika Berbasis Problem Open-Ended Terhadap Kemampuan Pemecahan Masalah Peserta Didik Kelas VII Semester II di SMP Kecamatan Semarang Timur Tahun Pelajaran 2006/2007. Skripsi : UNNES.

[2] Slameto. 2009. Belajar dan Faktor-Faktor yang Mempengaruhinya. Jakarta: Rineka Cipta.

[3] Iskandar. 2009. Penelitian Tindakan Kelas. Jakarta : Gaung Persada Press.

[4] Trianto. 2007. Model Pembelajaran Terpadu Dalam Teori dan Praktek. Jakarta : Prestasi Pustaka Publisher.

[5] Aloysius, Suyitno. Dkk.2007. IPA Terpadu 2. Bandung: Yudhistira

[6] Arikunto, Suharsimi, 2002. Dasar-Dasar Evaluasi Pendidikan. Jakarta : Bumi Aksara.

[7] Djamarah, Syaiful Bahri. 1994. Prestasi Belajar dan Kompetensi Guru. Surabaya:Usaha Nasional.

[8] Uno, Hamzah B. 2009. Model Pembelajaran Menciptakan Proses Belajar Mengajar yang Kreatif dan Efektif. Jakarta: Bumi Aksara.

[9] Utomo, Pristiadi. 2009. Discovery-Inquiry dalam Pembelajaran Fisika. http://ilmuwanmuda.wordpress.com/2009/02/03/discovery\%E2\%80\%93inquiry-dalam-pembelajaran-fisika/. Diakses tanggal 11 Oktober 2016, jam 16.31 WITA.

[10] Jupri, Al. 2007. Jurnal Pendidikan dan Budaya, Open Ended Problems Dalam Matematika: FKIP UNLA.

[11] Jacobsen, David dkk. 2009. Methods for Teaching, Metode-Metode Pengajaran Meningkatkan Belajar untuk TK-SMA. Yogyakarta: Pustaka Pelajar.

[12] Karim, Saeful. dkk. 2008. Belajar IPA Membuka Cakrawala Alam semesta Untuk Kelas VIII Sekolah Menengah Pertama/Madrasah Tsanawiah. Jakarta: Pusat Perbukuan Departemen Pendidikan Nasional.

[13] Nursepliana. Baiq Zulfa. 2007. Pengaruh Penerapan Model Pembelajaran Kooperatif Tipe Think-Pair-Share (TPS) Terhadap Motivasi Belajar Siswa di 
SMP Negeri 9 Mataram Tahun Ajaran 2006/2007.Skripsi : Universitas Mataram.

[14] Hamalik, Oemar. 2003. Proses Belajar Mengajar. Jakarata : PT Bumi Aksara

[15] Sagala, Syaiful. 2009. Konsep dan Makna Pembelajaran. Bandung : Alfabeta.

[16] Muda, Widyaiswara. 2009. Jurnal Pendidikan Pembelajaran Matematika dengan Pendekatan Open-Ended. Makassar: Balai Diklat Keagamaan Makassar.

[17] Sudjana, Nana. 2001. Tuntunan Penyusunan Karya Ilmiah. Bandung : Sinar Baru Algensindo Offset.

[18] Syaban, Mumun. Jurnal Pendidikan dan Budaya. Menggunakan Open-Ended untuk Motivasi Berpikir Matematika: FKIP UNLA.

[19] Takahashi, Akihiko. 2005. Education Journal, An Overview What is the Open Ended Approach. mathforum.org/pcmi/hstp/sum2005/morning/sstp.dayl.ppt. Diakses tanggal 11 Oktober 2016, jam 17.50 WITA.

[20] Sugiyono. 2008. Metode Penelitian Pendidikan. Bandung: Alfabeta

[21] Leksono, Joko Tri. 2006. Pengaruh Motivasi Belajar dan Kemampuan Berproses pada Pembelajaran Pendekatan Open-Ended Terhadap Hasil Belajar Siswa pada Pokok Bahasan Persamaan Garis Lurus Kelas VIII SMP Negeri 4 Pati. Skripsi: Universitas Negeri Semarang.

\section{Biografi Penulis}

Muhammad Kafrawi, lahir di Dompu tepatnya pada tanggal 2 Juli 1986. Pendidikan terakhir di Magister Pendidikan Fisika Universitas Ahmad Dahlan (UAD) Yogyakarta. Fokus kajian riset pendidikan, pengembangan dan Eksperimen Fisika. Dari Tahun 2017 sampai sekarang bekerja di Universitas Islam Negeri Mataram (UIN). 